\title{
CANINE VISCERAL LEISHMANIASIS CASE INVESTIGATION IN THE JACARE REGION OF NITEROI, RIO DE JANEIRO, BRAZIL
}

\author{
Amanda Codeco de OLIVEIRA(1), Fabiano Borges FIGUEIREDO(3), Valmir Laurentino SILVA(1), Fernanda Nunes SANTOS(1), \\ Marcos Barbosa de SOUZA(1), Maria de Fátima MADEIRA(2), Tuanne Rotti ABRANTES(3) \& André Reynaldo Santos PÉRISSÉ(1)
}

\begin{abstract}
SUMMARY
American visceral leishmaniasis is a vector-borne zoonosis in expansion in Brazil. Dogs are the main urban reservoir. Departing from a case of canine visceral leishmaniasis (CVL) in Jacaré, Niterói, Rio de Janeiro State, an epidemiological canine and entomological study was performed to assess the extension of the disease at the location. Sample was collected around the case and the dogs identified by serological tests (rapid double platform immunochromatographic exams, immunoenzymatic assay/ELISA, indirect immunofluorescence/IFAT). The parasitological diagnosis was performed in animals positive in at least one of these tests. The entomological study was carried out by using light traps and manual collection. The associations between canine variables and outcome (ELISA and IFAT reagents) were assessed by the chi-square test and adjusted by multivariate logistic regression for those associations with $\mathrm{p}<0.1$ in the bivariate analysis. Seventeen cases of CVL were detected among 110 evaluated dogs (prevalence of $15.5 \%$ ). Presence of ectoparasites (OR 6.5; 95\% CI 1.1-37.4), animals with clinical signs (OR 9.5; 95\% CI 1.2-76.6), and previous cases of CVL in the same house (OR 17.9; 95\% CI 2.2-147.1) were associated with the outcome. Lutzomyia longipalpis was not detected. Our results are indicative of an ongoing transmission in the area.
\end{abstract}

KEYWORDS: Visceral leishmaniasis; Epidemiology; Dogs.

\section{INTRODUCTION}

American visceral leishmaniasis is a vector-borne zoonosis that primarily affects children under 10 years old and adults in recent introduced areas ${ }^{56}$. The main agent responsible for the disease in Brazil is the Leishmania (Leishmania) chagasi (the same L. infantum) protozoan which is transmitted by the sand fly species Lutzomyia longipalpis. Some mammal hosts, such as foxes (Dusicyon vetulus and Cerdocyon thous) and marsupials (Didelphis albiventris) in the wild and domestic dogs (Canis familiaris) in urban areas are important reservoirs of the disease. ${ }^{34}$.

American visceral leishmaniasis is in frank expansion in several areas all over Brazil, and human and canine cases have been reported in both rural and urban areas ${ }^{6,16,34}$. In the Rio de Janeiro State, the first autochthonous case of human visceral leishmaniasis (HVL) was described in $1977^{28}$. From 2007 to 2012, 16 new cases were reported, five of them autochthonous from the cities of Miracema, Rio de Janeiro, Volta Redonda and Barra Mansa. Despite the small number of HVL, three deaths were reported during the same period, indicating a high fatality rate $^{30}$. Several cities in the Rio de Janeiro State have already reported cases of autochthonous canine visceral leishmaniasis (CVL) such as Marica $^{40}$, Rio de Janeiro city ${ }^{14}$, Mangaratiba and Angra dos Reis ${ }^{23}$. In
2011, an outbreak in the Rio de Janeiro harbor area ${ }^{41}$ predicted the spread of the disease to urban areas ${ }^{10,27}$.

Since the presence of a positive dog at home may be considered a risk factor for acquiring $\mathrm{HVL}^{5}$, new cases and the spread of the disease to unaffected areas should be investigated ${ }^{34}$. Herein, we assessed the prevalence of CVL in the studied area, from the first reported case, by using serological canine survey, parasitological characterization and entomological survey.

\section{MATERIAL AND METHODS}

The study was performed in the Jacaré district in the city of Niterói, which is located in the metropolitan region of the Rio de Janeiro State. The city's geographic coordinates are latitude $22^{\circ} 52^{\prime} 50.76^{\prime \prime} \mathrm{S}$ and longitude $43^{\circ} 6^{\prime} 15.61^{\prime \prime} \mathrm{W}$, and presents an average altitude of $5 \mathrm{~m}$ above sea level. Its average annual temperature is $23{ }^{\circ} \mathrm{C}$ with a predominantly hot and humid tropical weather. Niterói's 487,462 inhabitants live in a total area of $133,916 \mathrm{~km}^{2}{ }^{(18)}$. The Jacaré District is located in the coastal region (Fig. 1a); includes most of the Jacaré river watershed and the Darcy Ribeiro ecological reserve and presents a valley-type geographic characteristic ${ }^{4}$. Jacaré had a population of 3,563 inhabitants in $2010^{19}$. Its settlement

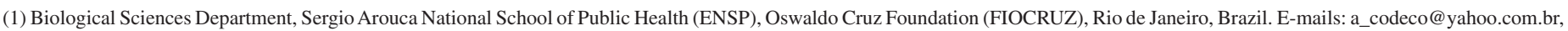
valmir@ensp.fiocruz.br, santosfn.vet@gmail.com, mabaza@ensp.fiocruz.br, aperisse@ensp.fiocruz.br

(2) Leishmaniasis Surveillance Laboratory, Evandro Chagas Clinical Research Institute (IPEC-FIOCRUZ), Rio de Janeiro, Brazil. E-mail: fatima.madeira@ipec.fiocruz.br

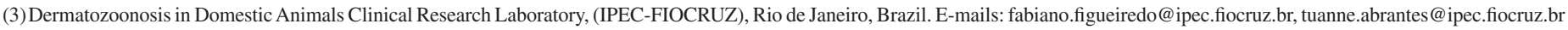
Correspondence to: Amanda Codeço de Oliveira. Phone: +55 21 25982584. E-mail: a_codeco@yahoo.com.br 


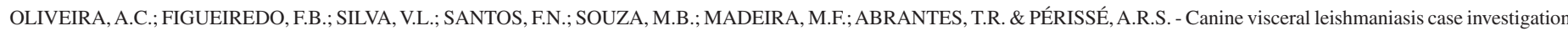
in the Jacare region of Niteroi, Rio de Janeiro, Brazil. Rev. Inst. Med. Trop. Sao Paulo, 57(4): 325-32, 2015.

process developed disorderly around its main street, Estrada Frei Orlando, which is parallel to the Jacaré river. Currently, the area consists of rural and unplanned urban communities with poor urban infrastructure.

In 2009, the first case of CVL was reported in the Jacaré District. A serological canine survey was performed, from December 2011 to March 2012, by actively searching for CVL cases according to the guidelines established by the National Program for Controlling of Visceral Leishmaniasis (NPCVL) ${ }^{34}$

The data collection form used in this study was the same used by the Evandro Chagas Clinical Research Institute of the Oswaldo Cruz Foundation (IPEC/FIOCRUZ) in its CVL field investigations. The following information was taken from the form and used in our analysis: gender, breed, age, coat length, weight in kilograms, presence of ectoparasites, coexistence with other animal species, location of the dwelling, place where the dog is kept at the residence, previous presence of dogs with CVL in the residence, and presence of compatible clinical signs of CVL.

The animals were classified by the presence of suggestive clinical signs of CVL as asymptomatic (without any symptoms), oligosymptomatic (presence of one to three symptoms) or symptomatic (more than three symptoms), according to the criteria used at the Laboratory of Clinical Research for Dermatozoonosis in Domestic Animals (LAPCLINDERMZOO/IPEC) adapted from MANCIANTI et l. $^{26}$.

The area was divided into three regions according to the geographical characteristics of the residence's location: forest, where residences were located within the borders of the ecological reserve; rural, where agricultural and livestock activities were present; urban, characterized by clusters and high proximity among the residences. The rural area was further divided according to the distance from the residence to the nearby forest, estimated from satellite images obtained from Google Earth@ software (free software, version 6.2 - available in earth.google. $\underline{\mathrm{com}}$ ). The distance was defined as the minimum radius, in meters, from the center of the residence to the nearest forest area, by using the "ruler" tool from the same software.

The rapid immunochromatographic Dual-Path Platform (DPP) test (Bio-Manguinhos/FIOCRUZ), used according to the manufacturer's instructions, was one of the tests that evaluated the canine serological status for CVL. The enzyme-linked immunoenzymatic assay (ELISA) was also used for this purpose and it was performed according to the VOLLER et al. method $^{55}$ by using a raw $L$. (L.) chagasi extract as the antigen and by setting the cutoff point of the test according to GUIMARÃES et al. ${ }^{17}$. Finally, we also used the indirect immunofluorescence antibody test (IFAT) with $L$. (L.) chagasi promastigotes following the CAMARGO et al. ${ }^{8}$ and COUTINHO et $a l .{ }^{12}$ methodologies. We defined a CVL-positive dog (study's outcome) as a dog that tested positive in both ELISA (screening test) and IFAT (confirmatory test at dilutions $\geq 1: 40)^{33}$.

In order to confirm the disease's transmissibility in the area, we collected intact skin fragments from the scapular region and aspirated bone marrow and lymph nodes to carry out the parasitological diagnosis. Samples were collected from positive animals in at least one of the serological tests, according to SILVA et al. ${ }^{48}$.
The entomological study took place between September 2011 and July 2012. On average, five light traps were used per month for 12 hours during the nocturnal period (from 6 p.m. to 6 a.m.), scattered in different residences near to the index case. Sites for vector collection were, preferentially, animal shelters such as stables, kennels and chicken coops, and locations nearby the forest and the residences. We also performed one 12 hours manual collection with Castro-type suction tubes. The captured sand flies were transferred to tubes containing alcohol $70 \%$. The identification of the flebotomines species was made according to the YOUNG \& DUNCAN criteria $^{57}$.

We started data analysis by describing the data. At this phase, variables were categorized and presented in their frequency distributions. We dichotomized the outcome into presence or absence of CVL based on the case definition used by the Brazilian Ministry of Health ${ }^{33}$, and the bivariate association between explanatory variables and the outcome were evaluated. Chi-square test (or exact Fisher, if $20 \%$ or more of the cells have expected value less than or equal to 5) was used in the bivariate analysis with a significance level of $5 \%$. All variables with a $p$-value $\leq 0.1$ in the exploratory analysis were used to generate the final multivariate model. We used the logistic regression model to test the association between variables selected in the explanatory analysis and the outcome. The resulting odds ratios represent the relative chance of CVL-positive dogs and the final variables in the model. All analysis was performed with SPSS Statistics $17.0^{\circledR}$.

This project was submitted and approved by the Ethics Committee in the Sérgio Arouca National School of Public Health of the Oswaldo Cruz Foundation (CEP/ ENSP/ FIOCRUZ) and registered under the protocol number 315/11 (CAAE: 0332.0.031.000-11). The project was also evaluated by the Animal Ethics Committee at FIOCRUZ (CEUAFIOCRUZ; protocol number 73/11-1).

\section{RESULTS}

We were able to examine 110 dogs (Table 1). A total of $32(29.1 \%)$ samples were reagent for ELISA, 28 (25.5\%) were DPP-positive and 24 $(21.8 \%)$ IFAT-positive. Twenty-three (20.9\%) dogs were both DPP and ELISA-positive. The area prevalence of CVL (ELISA and IFAT-positive) was $15.5 \%$ (17 out of $110 \mathrm{dogs}$ ) (Fig. 1b and 1c).

Five out of the $17(29.4 \%)$ positive animals were asymptomatic, another five (29.4\%) were oligosymptomatic, and seven (41.2\%) were symptomatic. The clinical examination performed in positive animals was able to detect eigth $(47.1 \%)$ animals with different skin lesions, eight $(47.1 \%)$ with onychogryphosis, six with $(35.3 \%)$ local alopecia, six (35.3\%) with furfuraceous desquamation, six $(35.3 \%)$ with opaque pelage, five $(29.5 \%)$ with crusted ulcers, five $(29.5 \%)$ with ophthalmological abnormalities, and five $(29.5 \%)$ with regional adenitis. Splenomegaly, hepatomegaly and pain in the abdominal examination were less frequent among the dogs (less than $12.5 \%$ each). Other clinical abnormalities such as appetite loss, weight loss, cachexia, generalized adenitis and limb edema were present in only a few cases.

During the bivariate analysis, we found a positive association for animals classified as symptomatic $(p<0.001)$ when compared to those asymptomatic, for animals with fleas and ticks $(p=0.038)$ compared to the others (fleas and myiasis, only ticks or absence of ectoparasites), and 
Table 1

Distribution of the main features present in the canine population of the Jacaré district, Niterói, Rio de Janeiro State, from December 2011 to March 2012

\begin{tabular}{|c|c|}
\hline Variable (n) & $\mathbf{N}(\%)$ \\
\hline \multicolumn{2}{|l|}{ Gender $(n=106)$} \\
\hline Male & $57(53.77)$ \\
\hline Female & $49(46.23)$ \\
\hline \multicolumn{2}{|l|}{ Breed $(n=109)$} \\
\hline SRD & $87(79.82)$ \\
\hline Poodle & $04(3.67)$ \\
\hline Pastor & $03(2.75)$ \\
\hline Pinsher & $04(3.67)$ \\
\hline Others* & $11(10.09)$ \\
\hline \multicolumn{2}{|l|}{ Age in years $(n=103)$} \\
\hline Under 1 & $12(11.65)$ \\
\hline Between 1 and 7 & $61(59.22)$ \\
\hline Above 7 & $30(29.13)$ \\
\hline \multicolumn{2}{|l|}{ Coat type $(n=102)$} \\
\hline Short & $77(75.49)$ \\
\hline Long & $25(24.51)$ \\
\hline \multicolumn{2}{|l|}{ Weight in kg $(n=74)$} \\
\hline Up to 10 & $37(50.00)$ \\
\hline 10 to 25 & $27(36.49)$ \\
\hline Above 25 & $10(13.51)$ \\
\hline \multicolumn{2}{|l|}{ Ectoparasites (n=97) } \\
\hline Fleas & $50(51.55)$ \\
\hline Ticks & $01(1.03)$ \\
\hline Fleas and Ticks & $20(20.62)$ \\
\hline Fleas and maggots & $01(1.03)$ \\
\hline Without ectoparasites & $25(25.77)$ \\
\hline \multicolumn{2}{|c|}{ Location of residence $(n=110)$} \\
\hline Woods & $08(7.27)$ \\
\hline Rural & $57(51.82)$ \\
\hline Urban & $45(40.91)$ \\
\hline \multicolumn{2}{|c|}{ Canine environment $(n=103)$} \\
\hline Backyard & $61(59.22)$ \\
\hline Indoors & $07(6.80)$ \\
\hline Street access & $35(33.98)$ \\
\hline \multicolumn{2}{|c|}{ Previous case of canine VL in the home $(n=105)$} \\
\hline No & $95(90.48)$ \\
\hline Yes & $10(9.52)$ \\
\hline \multicolumn{2}{|c|}{ Living with animals $(n=106)$} \\
\hline No & $11(10.48)$ \\
\hline Yes & $95(89.52)$ \\
\hline \multicolumn{2}{|c|}{ Living with other dogs $(n=106)$} \\
\hline No & $19(17.92)$ \\
\hline Yes & $87(82.08)$ \\
\hline \multicolumn{2}{|l|}{ Signs and Symptoms (103) } \\
\hline Asymptomatic & $62(60.19)$ \\
\hline Oligosymptomatic & $28(27.18)$ \\
\hline Symptomatic & $13(12.62)$ \\
\hline
\end{tabular}

*Other: Argentine Dogo, Brazilian Mastiff, Brazilian Terrier, Labrador, Rottweiler, Akita, Cocker Spaniel and Bull Terrier.

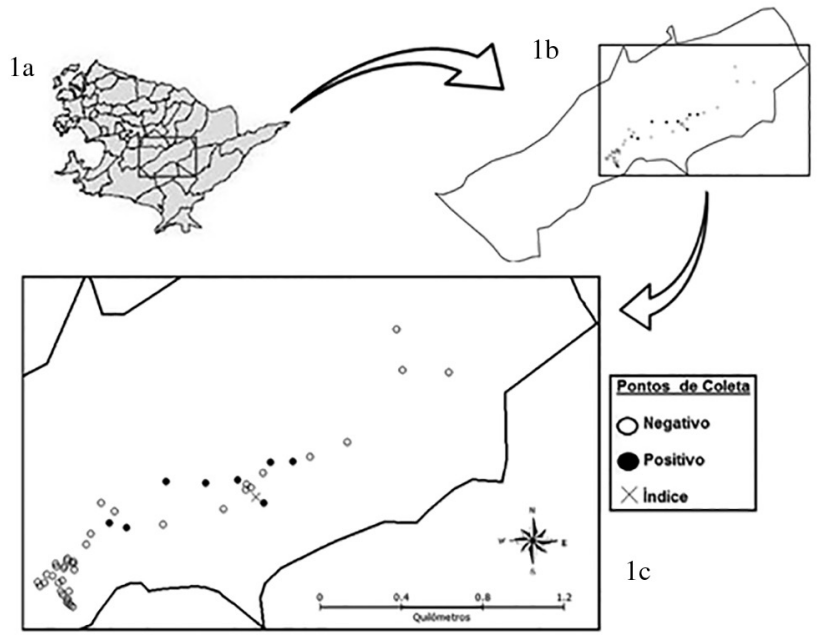

Fig. 1 - Illustrative map of Niterói (1a) and Jacaré district (1b), focusing on the collection points of the canine serological survey (1c), represented by the presence of at least one positive animal in the household.

for animals which lived in residences with a history of CVL $(p=0.001)$ vs. no prior illness (Table 2). It was not possible to analyze the association between residential area and outcome, since all animals were found in rural areas. The same happened when analyzing the contact among dogs and other animals since all positive cases interacted with other animals.

The presence of fleas and ticks resulted in a 6.5 times higher odds of a CVL-positive dog in the multivariate model, when compared to a group called "others" $(\mathrm{OR}=6.55,95 \% \mathrm{CI}=1.15$ to 37.40$)$. Symptomatic dogs showed a 9.5 times higher chance $(\mathrm{OR}=9.54,95 \% \mathrm{CI}=1.19$ to 76.57$)$ when compared to asymptomatic, and dogs living in households with a history of illness showed a 17.9 times higher chance $(\mathrm{OR}=17.83,95 \%$ $\mathrm{CI}=2.17$ to 147.01 ) compared to those from houses without previous CVL reports (Table 3).

Twenty-one samples out of 41 positive animals $(52.2 \%)$ in at least one serologic exam were collected for parasitological diagnosis. Parasitological growth in culture was detected in five samples (23.8\%). All cases were characterized as Leishmania chagasi, three samples $(14.3 \%)$ obtained from intact skin fragments, one (4.8\%) from normal skin and bone marrow, and one (4.8\%) from bone marrow. Among the dogs with parasite detection, four $(80 \%)$ were positive for DPP, ELISA and IFAT, and one $(20 \%)$ was positive for DPP and IFAT.

During the entomological survey we captured 323 sandflies, 237 males and 86 females, from the following species: Lutzomyia migonei (55.1\%), L. pelloni $(21.0 \%)$, L. intermediate (16.1\%), L. fischeri $(3.7 \%)$, L. schreiberi (2.2\%), L. tupinambai $(0.6 \%)$, L. bianchigalatiae $(0.6 \%)$, L. edwardsi $(0.3 \%)$ and Brumptomyia brumpti (0.3\%). No Lutzomyia longipalpis was captured during the survey.

\section{DISCUSSION}

Herein, we described the first serological CVL survey performed in Niterói, Rio de Janeiro State, a city so far considered as free of the diseas $\mathrm{e}^{30}$. One can indirectly confirm that the case was indeed 


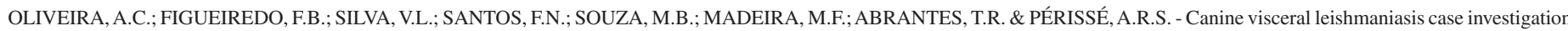
in the Jacare region of Niteroi, Rio de Janeiro, Brazil. Rev. Inst. Med. Trop. Sao Paulo, 57(4): 325-32, 2015.

Table 2

Association between variables and canine outcome, according to the Ministry of Health criteria of positivity, in the Jacaré district, Niterói, Rio de Janeiro State, from December 2011 to March 2012

\begin{tabular}{|c|c|c|c|c|c|c|}
\hline Variable (n) & $\begin{array}{c}\text { Positives } \\
\mathbf{n}(\%)\end{array}$ & $\begin{array}{c}\text { Negatives } \\
\mathbf{n}(\%)\end{array}$ & $p$-value & OR & \multicolumn{2}{|c|}{ IC $(95 \%)$} \\
\hline \multicolumn{7}{|l|}{ Gender (n=106) } \\
\hline Male & $06(35.29)$ & $51(57.3)$ & 0.095 & 0.41 & 0.14 & 1.20 \\
\hline Female & $11(64.71)$ & $38(42.7)$ & Reference & - & - & - \\
\hline \multicolumn{7}{|l|}{ Breed $(n=109)$} \\
\hline With defined Breed & $03(17.65)$ & $19(20.65)$ & 1.00 & 1.22 & 0.32 & 4.66 \\
\hline Without defined Breed (SRD) & $14(82.35)$ & $73(79.35)$ & Reference & - & - & - \\
\hline \multicolumn{7}{|l|}{ Age in years $(n=103)$} \\
\hline Under 07 & $09(56.25)$ & $64(73,56)$ & 0.23 & 2.16 & 0.72 & 6.48 \\
\hline Above 07 & 07 (43.74) & $23(26.44)$ & Reference & - & - & - \\
\hline \multicolumn{7}{|l|}{ Coat type $(n=102)$} \\
\hline Short & $11(68.75)$ & $66(76.71)$ & 0.53 & 1.50 & 0.47 & 4.83 \\
\hline Long & $05(31.25)$ & $20(23.26)$ & Reference & - & - & - \\
\hline \multicolumn{7}{|l|}{ Weight in kg $(n=74)$} \\
\hline Up to 10 & $05(33.33)$ & $32(54.24)$ & 0.61 & 0.63 & 0.10 & 3.83 \\
\hline 10 to 25 & $08(53.33)$ & $19(32.20)$ & 0.56 & 1.68 & 0.29 & 9.75 \\
\hline Above 25 & $02(13.33)$ & $08(13.56)$ & Reference & - & - & - \\
\hline \multicolumn{7}{|l|}{ Ectoparasites $(\mathbf{n = 9 7})$} \\
\hline Fleas & $06(35.29)$ & $45(56.25)$ & 0.98 & 1.02 & 0.23 & 4.46 \\
\hline Fleas and Ticks & $08(47.06)$ & $12(15.00)$ & 0.033 & 5.11 & 1.14 & 22.89 \\
\hline Others* & $03(17.65)$ & $23(28.75)$ & Reference & - & - & - \\
\hline \multicolumn{7}{|l|}{ Signs and symptoms $(n=103)$} \\
\hline Assymptomatic & $05(29.41)$ & $57(66.28)$ & Reference & - & - & - \\
\hline Oligosymptomatic & $05(29.41)$ & $23(26.74)$ & 0.18 & 2.48 & 0.66 & 9.38 \\
\hline Symptomatic & $07(41.18)$ & $06(6.98)$ & $<0.001$ & 13.30 & 3.21 & 55.19 \\
\hline \multicolumn{7}{|c|}{ Previous case of canine VL in the home $(n=105)$} \\
\hline Yes & $06(35.29)$ & $04(4.55)$ & 0.001 & 11.46 & 2.79 & 47.04 \\
\hline No & $11(64.71)$ & $84(95.45)$ & Reference & - & - & - \\
\hline \multicolumn{7}{|c|}{ Proximity from the woods in the rural area in meters $(n=57)$} \\
\hline Up to 25 & $13(76.47)$ & $21(52.50)$ & 0.19 & 4.33 & 0.48 & 39.36 \\
\hline 25 to 50 & $01(5.88)$ & $07(17.50)$ & 1.00 & 1.00 & 0.05 & 19.36 \\
\hline 50 to 75 & $02(11.76)$ & $05(12.50)$ & 0.45 & 2.80 & 0.20 & 40.06 \\
\hline Above 75 & $01(5.88)$ & $07(17,50)$ & Reference & - & - & - \\
\hline \multicolumn{7}{|l|}{ Canine environment ( $n=103$ ) } \\
\hline Backyard & $11(64.71)$ & $50(58.14)$ & 0.81 & 1.32 & 0.14 & 12.01 \\
\hline Inside the home & $01(5.88)$ & $06(6.98)$ & Reference & - & - & - \\
\hline Street access & $05(29.41)$ & $30(34.88)$ & 1.00 & 1.00 & 0.10 & 10.17 \\
\hline \multicolumn{7}{|l|}{ Living with other animals $(n=106)$} \\
\hline No & $0(0.0)$ & $11(12.36)$ & 0.21 & - & - & - \\
\hline Yes & $17(100.0)$ & $78(87.64)$ & Reference & - & - & - \\
\hline
\end{tabular}

*Others: without Ectoparasites. Ticks or Fleas and myiasis.

autochthonous by the dog's medical history (a young dog with no history of any travel outside the area), the detection of Leishmania sp. antibodies and by the isolation of L. chagasi in other dogs, since it was not possible to verify the presence of the vector in the area, as required by the NPCVL ${ }^{34}$.
The prevalence of infected dogs in Jacaré - Niterói was 15.5\%, similar to other areas also considered as disease-free ${ }^{45}$. Prevalence rates, even in endemic areas, may present large variation as demonstrated by rates from Cuiabá, Mato Grosso State $(3.4 \%)^{1}$, Dias D'Ávila, Bahia State $(6.7 \%)^{39}$ 


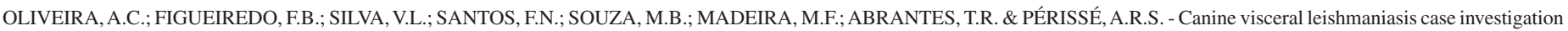
in the Jacare region of Niteroi, Rio de Janeiro, Brazil. Rev. Inst. Med. Trop. Sao Paulo, 57(4): 325-32, 2015.

Table 3

Odds ratio (odds ratio - OR) and adjusted OR for CVL-positive among dogs evaluated in the Jacaré district, Niterói, Rio de Janeiro State, from December 2011 to March 2012

\begin{tabular}{|c|c|c|c|c|c|c|c|c|}
\hline $\begin{array}{l}\text { Variable } \\
\text { Gender }\end{array}$ & $\begin{array}{c}\text { Non-adjusted } \\
\text { OR }\end{array}$ & \multicolumn{2}{|c|}{ IC (95\%) } & $p$-value & Adjusted OR & \multicolumn{2}{|c|}{ IC $(95 \%)$} & $p$-value \\
\hline Female & 0.41 & 0.14 & 1.20 & 0.095 & 0.56 & 0.14 & 2.23 & 0.41 \\
\hline Male & Reference & - & - & - & Reference & - & - & - \\
\hline \multicolumn{9}{|l|}{ Ectoparasites } \\
\hline Fleas & 1.02 & 0.23 & 4.47 & 1.00 & 0.23 & 0.03 & 2.03 & 0.19 \\
\hline Fleas and Ticks & 5.11 & 1.14 & 22.90 & 0.033 & 6.55 & 1.15 & 37.40 & 0.035 \\
\hline Others $* *$ & Reference & - & - & - & Reference & - & - & - \\
\hline \multicolumn{9}{|l|}{ Symptoms } \\
\hline Asymptomatic & Reference & - & - & - & Reference & - & - & - \\
\hline Oligosymptomatic & 2.48 & 0.66 & 9.38 & 0.18 & 1.18 & 0.25 & 5.65 & 0.84 \\
\hline Symptomatic & 13.30 & 3.26 & 55.19 & $<0.001$ & 9.54 & 1.20 & 76.57 & 0.034 \\
\hline \multicolumn{9}{|c|}{ Previous case of canine VL in the home } \\
\hline Yes & 11.46 & 2.79 & 47.04 & 0.001 & 17.85 & 2.17 & 147.09 & 0.007 \\
\hline No & Reference & - & - & - & Reference & - & - & - \\
\hline
\end{tabular}

* Sex, presence of ectoparasites, symptomatology and previous case of CVL in the residence; **Others: without Ectoparasites, Ticks or Fleas and Myiasis.

and Rio de Janeiro city, Rio de Janeiro State $(25 \%)^{47}$. Such variability is due not only to the different characteristics of each area, but also to the diversity of employed sampling methods and laboratory techniques ${ }^{3,13,42}$. The lack of standardization of the techniques used in the studies can be detrimental in assessing the extent of the disease, and in establishing priority control areas in cities.

In order to minimize these difficulties, the Brazilian Ministry of Health proposed a change in the criteria for serologic diagnosis of CVL, with the inclusion of DPP as the screening test, and ELISA as the confirmatory method. ELISA was chosen, instead of IFAT, because of its higher reproducibility ${ }^{31}$. If we apply these new criteria in our study, the prevalence rate increases to $20.9 \%$ in the area. Since the control actions seek to prevent that human cases are preceded by canine outbreaks ${ }^{9,37,38}$, highly accurate definitions are essential in order to avoid both the permanence of false-negative dogs and the euthanasia of false-positives dogs in these $\operatorname{areas}^{23,43}$.

Similar to us, several other studies indicated that there was no association between positive animals and gender ${ }^{2,7,36,45}$, breed ${ }^{20,36}$, age $^{2,20,36,45}$, weight ${ }^{54}$, coat length ${ }^{39}$ and the animal's environment ${ }^{7,36}$. However, other studies have found a positive correlation between these very same variables ${ }^{20,36,39}$. Such inconsistencies regarding the association of risk factors and characteristics related to the dogs, may be attributed to the circumstantial epidemiological role of the disease and the level of interaction between owners and their pets, which implies different ways of exposure to vectors and, therefore, different probabilities of infection transmission ${ }^{11,20,21,45}$.

The presence of a high number of positive animals with clinical signs of CVL differs from 40 to $60 \%$ frequency of asymptomatic dogs often found in the biomedical literature ${ }^{39,45,56}$. Such difference could be attributed to the results found in endemic areas in which dogs with clinical signs of disease are quickly directed to serologic testing and forwarded to euthanasia. In contrast, in disease-free areas, the lack of clinical suspicion of CVL could delay diagnosis by indicating other etiologies ${ }^{20}$. Skin changes such as ulcerated lesions, onychogryphosis, alopecia, furfuraceous desquamation and opaque pelage were the most described clinical signs in our study and, although nonspecific, they have been frequently observed in the disease $\mathrm{e}^{2,39,42}$.

The proximity between residences and circumscribed forest areas may be associated with the acquisition of canine infection ${ }^{1,7}$. However, in our study, all positive animals were located at a distance inferior to 100 meters from the nearby forest area, preventing us from analyzing such association. This could be due to the characteristics of Jacaré, where even in rural areas households have close proximity to the edge of the forest. Also, the presence of breeding livestock in the area could provide favorable conditions for vector adaptation to the peridomicile ${ }^{21}$.

Reports of previous cases of CVL in the same area were unanticipated due to the mandatory reporting of the disease by veterinarians ${ }^{32}$. Underreporting may favor the spread of the disease through the absence of effective control measures and maintenance of infected animals in the area $^{16}$. Since the diagnosis was not performed on all dogs of the residence in the first case in 2009, and they remained there until our current study, this may have contributed to the greater chance to find seropositive dogs in these residences. A previous study in the Bahia State did not find any association with local history of CVL and indicated other possible local risk variables such as the presence of other domestic and wild animals in the peridomicile ${ }^{20}$. In a case-control study, such association was observed 


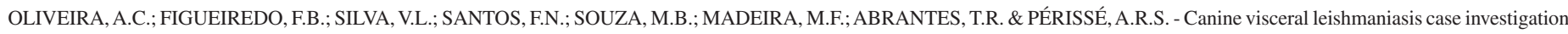
in the Jacare region of Niteroi, Rio de Janeiro, Brazil. Rev. Inst. Med. Trop. Sao Paulo, 57(4): 325-32, 2015.

even in residences that had sent dogs for euthanasia in the previous 12 months, and the authors justified this association by the ineffectiveness of euthanasia as a measure to control CVL ${ }^{50}$.

The existence of overlapping areas of mucocutaneous and visceral leishmaniasis in nearby cities such as Maricá $a^{25,40}$ and Rio de Janeiro ${ }^{22,23}$, reinforces the need for parasitological confirmation in areas reporting the first cases, since euthanasia of dogs is not recommended for American cutaneous leishmaniasis $^{35}$. In Niterói, the presence of antibodies to Leishmania sp. has been reported, although without parasitic identification, so far assuming that the infection was due to the cutaneous form ${ }^{24,29}$. Only after our study with the index case it was possible to isolate the protozoan and characterize the organism as L. chagasi. Despite the small number of collected parasitological samples due to several logistic problems faced by the study team during the current survey, such as the absence of owners or animals in the residence during the visit, the use of parasitological diagnosis with subsequent finding of the agent in other dogs confirms the circulation of the parasite in the area.

The entomological survey was not able to detect the presence of Lutzomyia longipalpis in the study area as it was done in the districts of Angra dos Reis ${ }^{52}$ and in Rio de Janeiro ${ }^{53}$. FUZARI et al. ${ }^{15}$ found a very low density of L. longipalpis at the Serra da Tiririca, an area limiting the cities of Maricá and Niterói. However, the report of L. longipalpis in nearby areas does not rule out the possibility that other mechanisms of transmission may be occurring, either by sexual ${ }^{49}$ or vectorial routes by other sandfly species ${ }^{44,46}$, or even ticks ${ }^{51}$, considering the association found between positive animals with ectoparasites and spatial targeting of observed canine epizootic as described in this study.

Our results are indicative of an ongoing transmission in the area. Despite the limitation of a cross-sectional design, the observed high prevalence of CVL and the identification of $L$. chagasi in positive dogs indicate a possibility of a disease spread among dogs in the research area from the 2009 index case or other unidentified source. These results may be due to the long period between the occurrence of the first case and the current canine serological survey. Based on our results, we recommend that control measures should be carried out in the area in order to reduce the outbreak and prevent the spread of the disease to other districts in the same city. Our findings also suggest that the area should be monitored for a longer time period so that questions such as the mode of infection transmission and the absence of the vector can be answered in order to minimize human risk.

\section{RESUMO}

\section{Investigação de caso de leishmaniose visceral canina na região do} Jacaré, município de Niterói, Rio de Janeiro, Brasil

A leishmaniose visceral americana é zoonose em expansão no Brasil com transmissão vetorial, onde o cão é o principal reservatório urbano. Partindo de um caso canino da doença no Jacaré, Niterói/RJ, realizouse inquérito epidemiológico canino e levantamento entomológico para avaliar a extensão da enfermidade na localidade. As amostras foram coletadas ao redor do caso e os cães identificados por testes sorológicos (teste rápido de imunocromatografia em dupla plataforma, ensaio imunoenzimático/ELISA, reação de imunofluorescência indireta/RIFI). O diagnóstico parasitológico foi realizado nos animais reagentes em ao menos um desses exames. O levantamento entomológico foi feito com armadilhas luminosas e coleta manual. As associações entre variáveis caninas coletadas e o desfecho (ELISA e RIFI reagentes) foram avaliadas pelo teste qui-quadrado e ajustadas pela regressão logística multivariada para variáveis $\operatorname{com} p<0,1$ na análise bivariada. Foram detectados 17 casos de LVA entre os 110 cães avaliados (prevalência de 15,5\%). Presença de ectoparasitas (OR 6,5; 95\% IC 1,1-37,4), animais com sinais clínicos (OR 9,5; 95\% IC 1,2-76,6) e casos prévios de LVA canina na residência (OR 17,9; 95\% IC 2,2-147,1) foram associados ao desfecho. Não foi detectada Lutzomyia longipalpis. Nossos resultados indicam situação de transmissão contínua na área.

\section{ACKNOWLEDGMENTS}

We would like to thank the Conselho Nacional de Desenvolvimento Científico e Tecnológico (CNPq) and the Fundação de Apoio à Pesquisa do Estado do Rio de Janeiro (FAPERJ) for the financial support, and the Centro de Controle de Zoonoses da Prefeitura Municipal de Niterói and the lecturers of the Departamento de Saúde Pública of the Faculdade de Medicina Veterinária of the Universidade Federal Fluminense for their logistical support.

\section{CONTRIBUTIONS OF AUTHORS}

Amanda Codeço de Oliveira: project coordination, entomological and canine serological data analysis and the processing steps for the canine serological steps. Fabiano Borges Figueiredo: mentorship and study coordination, and CVL serological and parasitological research. Valmir Laurentino Silva: CVL serological research. Fernanda Nunes Santos: CVL serological research. Marcos Barbosa de Souza: entomological evaluation and identification. Maria de Fátima Madeira: parasitological research diagnosis and processing. Tuanne Rotti Abrantes: canine parasitological and serological data collection. André Reynaldo Santos Périssé: mentorship, study coordination and data analysis.

\section{CONFLICT OF INTEREST}

The authors have declared that there were no conflicts of interest during the development of the study. This article has been read by all of its authors and is considered representative of the work performed.

\section{FINANCIAL SUPPORT}

This study was funded by the financial support of the Conselho Nacional de Desenvolvimento Científico e Tecnológico (CNPq) and Fundação de Apoio à Pesquisa do Estado do Rio de Janeiro (FAPERJ).

\section{REFERENCES}

1. Almeida ABPF, Faria RP, Pimentel MF, Dahroug MA, Turbino NC, Sousa VR. Inquérito soroepidemiológico de leishmaniose canina em áreas endêmicas de Cuiabá, Estado de Mato Grosso. Rev Soc Bras Med Trop. 2009;42:156-9.

2. Almeida ABPF, Mendonça AJ, Sousa VRF. Prevalência e epidemiologia da leishmaniose visceral em cães e humanos, na cidade de Cuiabá, Mato Grosso, Brasil. Ciênc Rural. 2010;40:1610-5.

3. Azevedo MÁA, Dias AKK, Paula HB, Perri SHV, Nunes CM. Avaliação da leishmaniose visceral canina em Poxoréo, Estado do Mato Grosso, Brazil. Rev Bras Parasitol Vet. 2008;17:123-7. 

in the Jacare region of Niteroi, Rio de Janeiro, Brazil. Rev. Inst. Med. Trop. Sao Paulo, 57(4): 325-32, 2015.

4. Baptista JV, Fernandes VF, editores. Alterações ambientais em decorrência do processo de urbanização acelerada na bacia hidrográfica do Rio Jacaré, Niterói - RJ. Seminários de Recursos Hídricos da Bacia Hidrográfica do Paraíba do Sul: recuperação de áreas degradadas, serviços ambientais e sustentabilidade; 2009 dezembro 9-11. Taubaté: Seminários de Recursos Hídricos da Bacia Hidrográfica do Paraíba do Sul; 2009.

5. Belo VS. Fatores associados à leishmaniose visceral nas Américas [Dissertação]. Rio de Janeiro: Escola Nacional de Saúde Pública Sérgio Arouca, Fundação Oswaldo Cruz; 2012

6. Bevilacqua PD, Paixão HH, Modena CM, Castro MCPS. Urbanização da leishmaniose visceral em Belo Horizonte. Arq Bras Med Vet Zootec. 2001;53(1):1-8.

7. Cabrera MAA, Paula AA, Camacho LAB, Marzochi MCA, Xavier SC, Silva AVM, et al. Canine visceral leishmaniasis in Barra de Guaratiba, Rio de Janeiro, Brazil: assessment of risk factors. Rev Inst Med Trop Sao Paulo. 2003;45:79-83.

8. Camargo ME, Rebonato C. Cross-reactivity in fluorescence tests for Trypanosoma and Leishmania antibodies a simple inhibition procedure to ensure specific results. Am J Trop Med Hyg. 1969;18:500-5.

9. Camargo-Neves VLF, Katz G, Rodas LAC, Poletto DW, Lage LC, Spínola RMF, et al. Utilização de ferramentas de análise espacial na vigilância epidemiológica de leishmaniose visceral americana, Araçatuba, São Paulo, Brasil, 1998-1999. Cad Saude Publica. 2001;17:1263-7.

10. Costa CHN. Characterization and speculations on the urbanization of visceral leishmaniasis in Brazil. Cad Saude Publica. 2008:24:2959-63.

11. Coura-Vital W, Reis AB, Fausto MA, Leal GG, Marques MJ, Veloso VM, et al. Risk factors for seroconversion by Leishmania infantum in a cohort of dogs from an endemic area of Brazil. PLOS ONE. 2013;8:e71833. doi: http://dx.doi.org/10.1371/ journal.pone.0071833.

12. Coutinho SG, Souza WJS, Camillo-Coura L, Marzochi MCA, Amendoeira MRR. Levantamento dos resultados das reações de imunofluorescência indireta para toxoplasmose em 6079 pacientes de ambulatório ou gestantes no Rio de Janeiro realizadas durante o exame de 1970-1977. Rev Inst Med Trop Sao Paulo.1981;23:48-56.

13. Dantas-Torres F. Situação atual da epidemiologia da leishmaniose visceral em Pernambuco. Rev Saude Publica. 2006;40:537-41

14. Figueiredo FB, Barbosa Filho CJL, Schubach EYP, Pereira SA, Nascimento LD, Madeira MF. Relato de caso autóctone de leishmaniose visceral canina na zona sul do município do Rio de Janeiro. Rev Soc Bras Med Trop. 2010;43:98-9.

15. Fuzari AA, BarbosaVA, Andrade Filho JD, Brasil RP. Study of sand flies fauna (Diptera: Psychodidae: Phlebotominae) of Parque Estadual da Serra da Tiririca, Rio de Janeiro, Brazil. In: $7^{\text {th }}$ International Symposium on Phlebotomine Sandflies. April 25-30, 2011. Kusadasi, Turkey; 2011.

16. Gontijo CMF, Melo MN. Leishmaniose visceral no Brasil: quadro atual, desafios e perspectivas. Rev Bras Epidemiol. 2004;7:338-49.

17. Guimarães MCS, Coutinho SG, Antunes CMF. Normas para a sorologia de moléstias infecciosas e parasitárias. Rev Soc Bras Med Trop. 1987;20:55-8.

18. Instituto Brasileiro de Geografia e Estatística. Brasil: IBGE; 2011. [cited 2011, Jun 04]. Avaliable from: http://www.ibge.gov.br/cidadesat/topwindow.htm?

19. Instituto Brasileiro de Geografia e Estatística. Brasil: IBGE; 2011. [cited 2011, Oct 07]. Avaliable from: http://www.sidra.ibge.gov.br/bda/tabela/protabl. asp?c $=3107 \& \mathrm{z}=\mathrm{t} \& \mathrm{o}=4 \& \mathrm{i}=\mathrm{P}$

20. Julião FS, Souza B, Freitas DS, Oliveira LS, Laranjeira DF, Dias-Lima AG, et al. Investigação de áreas de risco como metodologia complementar ao controle da leishmaniose visceral canina. Pesq Vet Bras. 2007;27:319-24.
21. Lainson R, Rangel EF. Lutzomyia longipalpis and the eco-epidemiology of American visceral leishmaniasis, with particular reference to Brazil: a review. Mem Inst Oswaldo Cruz. 2005;100:811-27.

22. Madeira MF, Schubach A, Schubach TMP, Pacheco RS, Oliveira FS, Pereira SA, et al. Mixed infection with Leishmania (Viannia) braziliensis and Leishmania (Leishmania) chagasi in a naturally infected dog from Rio de Janeiro, Brazil. Trans R Soc Trop Med Hyg. 2006;100:442-5.

23. Madeira MF, Schubach A, Schubach TMP, Pereira SA, Figueiredo FB, Baptista C, et al. Post mortem parasitological evaluation of dogs seroreactive for Leishmania from Rio de Janeiro, Brazil. Vet Parasitol. 2006;138(3-4):366-70.

24. Madeira MF, Serra CMB, Uchôa CMA, Duarte R, Cruz DAM, Perdomo CC. Leishmaniose canina: avaliação sorológica de 310 cães na região de Itaipu, Rio de Janeiro. Cad Saúde Publica. 2000;16:568

25. Madeira MF, Uchôa CMA, Leal CA, Silva RMM, Duarte R, Magalhães CM, et al. Leishmania (Viannia) braziliensis em cães naturalmente infectados. Rev Soc Bras Med Trop. 2003;36:551-5

26 Mancianti F, Gramiccia M, Gradoni L, Pieri S. Studies on canine leishmaniasis control 1. Evolution of infection of different clinical forms of canine leishmaniasis following antimonial treatment. Trans R Soc Trop Med Hyg. 1988;82:566-7.

27. Marzochi MCA, Fagundes A, Andrade MV, Souza MB, Madeira MF, Mouta-Confort E, et al. Visceral leishmaniasis in Rio de Janeiro, Brazil: eco-epidemiological aspects and control. Rev Soc Bras Med Trop. 2009:42:570-80.

28. Marzochi MCA, Sabroza PC, Toledo LM, Marzochi KBF, Tramontano NC, Rangel Filho FB. Leishmaniose visceral na cidade do Rio de Janeiro-Brasil. Cad Saude Pública. 1985;1:5-17.

29. Mattos DG Jr, Pinheiro JM, Menezes RC, Costa DA. Aspectos clínicos e de laboratório de cães soropositivos para leishmaniose. Arq Bras Med Vet Zootec. 2004;56:119-22.

30. Ministério da Saúde. Brasil. Departamento de informática do SUS (DATASUS); 2012. [cited 2012 Oct 24]. Avaliable from: http://dtr2004.saude.gov.br/sinanweb/

31. Ministério da Saúde. Brasil. Nota técnica conjunta no 01/2011- CGDT-CGLAB/ DEVIT/SVS/MS. Esclarecimentos sobre substituição do protocolo diagnóstico da leishmaniose visceral canina (LVC). Brasília: Ministério da Saúde; 2011

32. Ministério da Saúde. Brasil. Nota técnica ${ }^{\circ} 02$ de fevereiro de 2008. Leishmaniose visceral canina: legislação vigente para as ações de controle do reservatório doméstico na leishmaniose visceral. Brasília: Ministério da Saúde; 2008.

33. Ministério da Saúde. Brasil. Nota técnica $n^{\circ} 48$ de setembro de 2011. Esclarecimentos sobre o diagnóstico sorológico da leishmaniose visceral canina utilizado na rede pública de saúde. Brasília: Ministério da Saúde; 2011.

34. Ministério da Saúde. Brasil. Secretaria de Vigilância em Saúde. Departamento de Vigilância Epidemiológica. Manual de vigilância e controle da leishmaniose visceral. Brasília: Ministério da Saúde; 2006.

35. Ministério da Saúde. Brasil. Secretaria de Vigilância em Saúde. Manual de vigilância da leishmaniose tegumentar americana. Brasília: Ministério da Saúde; 2007.

36. Moreira ED Jr, Souza VMM, Sreenivasan M, Lopes NL, Barreto RB, De Carvalho LP. Peridomestic risk factors for canine leishmaniasis in urban dwellings: new findings from a prospective study in Brazil. Am J Trop Med Hyg. 2003;69:393-7.

37. Nunes MP, Jackson JM, Carvalho RW, Furtado NJ, Coutinho SG. Serological survey for canine cutaneous and visceral leishmaniasis in areas at risk for transmission in Rio de Janeiro where prophylactic measures had been adopted. Mem Inst Oswaldo Cruz. 1991;86:411-7.

38. Oliveira CDL, Assunção RM, Reis IA, Proietti FA. Spatial distribution of human and canine visceral leishmaniasis in Belo Horizonte, Minas Gerais State, Brasil, 19941997. Cad Saude Publica. 2001;17:1231-9. 
OLIVEIRA, A.C.; FIGUEIREDO, F.B.; SILVA, V.L.; SANTOS, F.N.; SOUZA, M.B.; MADEIRA, M.F.; ABRANTES, T.R. \& PÉRISSÉ, A.R.S. - Canine visceral leishmaniasis case investigation in the Jacare region of Niteroi, Rio de Janeiro, Brazil. Rev. Inst. Med. Trop. Sao Paulo, 57(4): 325-32, 2015.

39. Oliveira LCP, Araújo RRD, Alves CR, Mouta-Confort E, López JA, Mendonça-Lima FWM. Seroprevalence and risk factors for canine visceral leishmaniasis in the endemic area of Dias D’Ávila, State of Bahia, Brazil. Rev Soc Bras Med Trop. 2010;43:400-4.

40. Paula CC, Figueiredo FB, Menezes RC, Moura-Confort E, Bogio A, Madeira M. Leishmaniose visceral canina em Maricá, Estado do Rio de Janeiro: relato do primeiro caso autóctone. Rev Soc Bras Med Trop. 2009;42:77-8.

41. Prefeitura da Cidade do Rio de Janeiro. Secretaria Municipal de Saúde e Defesa Civil. Subsecretaria de Vigilância, Fiscalização Sanitária e Controle de Zoonoses. Superintendência de Vigilância e Fiscalização Sanitária em Zoonoses. Nota técnica n. ${ }^{\circ}$ 01/2011/s/SUBVISA/ SVFSZ. Orientações sobre vigilância, prevenção e controle da leishmaniose visceral (LV) em caninos, no município do Rio de Janeiro, em virtude da confirmação de transmissão canina da doença, no bairro do Caju: área programática 1.0. Rio de Janeiro: Prefeitura da Cidade do Rio de Janeiro; 2011.

42. Reis AB, Teixeira-Carvalho A, Giunchetti RC, Roatt BM, Coura-Vital W, Nicolato RC, et al. Cellular immunophenotypic profile in the splenic compartment during canine visceral leishmaniasis. Vet Immunol Immunopathol. 2014:157(3-4):190-6.

43. Romero GA, Boelaert M. Control of visceral leishmaniasis in Latin America: a systematic review. PLOS Negl Trop Dis. 2010;4:e584.

44. Salomón OD, Quintana MG, Bezzi G, Morán ML, Betbeder E, Valdez DV. Lutzomyia migonei as putative vector of visceral leishmaniasis in La Banda, Argentina. Acta Trop. 2010;113:84-7.

45. Santos JML, Dantas-Torres F, Mattos MRF, Lino FRL, Andrade LSS, Souza RCA, et al. Prevalência de anticorpos antileishmania spp em cães de Garanhuns, Agreste de Pernambuco. Rev Soc Bras Med Trop. 2010;43:41-5.

46. Santos SO, Arias J, Ribeiro AA, de Paiva Hoffmann M, de Freitas RA, Malacco MA. Incrimination of Lutzomyia cruzi as a vector of American visceral leishmaniasis. Med Vet Entomol. 1998;12:315-7.

47. Silva AVM, Paula AA, Cabrera MAA, Carreira JCA. Leishmaniose em cães domésticos: aspectos epidemiológicos. Cad Saude Publica. 2005;21:324-8.

48. Silva DA, Madeira MF, Teixeira AC, de Souza CM, Figueiredo FB. Laboratory tests performed on Leishmania seroreactive dogs euthanized by the leishmaniasis control program. Vet Parasitol. 2011;179(1-3):257-61.
49. Silva FL, Oliveira RG, Silva TMA, Xavier MN, Nascimento EF, Santos RL. Venereal transmission of canine visceral leishmaniasis. Vet Parasitol. 2009;160(1-2):55-9.

50. Silva JP, Werneck GL, Macedo EC, Carvalho H, Cruz MS. Factors associated with Leishmania chagasi infection in domestic dogs from Teresina, State of Piauí, Brazil. Rev Soc Bras Med Trop. 2012;45:480-4.

51. Solano-Gallego L, Rossi L, Scroccaro AM, Montarsi F, Caldin M, Furlanello T, et al Detection of Leishmania infantum DNA mainly in Rhipicephalus sanguineus male ticks removed from dogs living in endemic areas of canine leishmaniosis. Parasit Vectors. 2012;5:98

52. Souza MB, Carvalho RW, Machado RNM, Wermelinger ED. Flebotomíneos de áreas com notificações de casos autóctones de leishmaniose visceral canina e leishmaniose tegumentar americana em Angra dos Reis, Rio de Janeiro, Brasil. Rev Bras Entomol. 2009;53:147-50.

53. Souza MB, Marzochi MCA, Carvalho RW, Ribeiro PC, Pontes CS, Caetano JM, et al Ausência da Lutzomyia longipalpis em algumas áreas de ocorrência de leishmaniose visceral no Município do Rio de Janeiro. Cad Saude Publica. 2003;19:1881-5.

54. Souza VMM, Julião FS, Neves RCS, Oliveira LC, Magalhães PB, Leal DC, et al. Estudo epidemiológico de um surto de leishmaniose visceral numa área de manguezal. Gaz Med Bahia. 2006;76:14-24.

55. Voller A, Bidwell DE, Bartlett A. Enzyme immunoassays in diagnostic medicine. Theory and practice. Bull World Health Organ. 1976;53:55-65.

56. World Health Organization. Control of the leishmaniasis: report of a meeting of the WHO Expert Committee on the Control of Leishmaniases. Geneva: WHO; 2010. (Tech. Rep. Ser. 949).

57. Young DG, Duncan MA. Guide to the identification and geographic distribution of Lutzomyia sand flies in Mexico, the West Indies, Central and South America (Diptera: Psychodidae). Gainesville: Memoirs Am Ent Inst; 1994.

Received: 12 November 2013

Accepted: 15 December 2014 